\title{
The Effects of Heat Treatment on the Physical Properties and Surface Roughness of Turkish Hazel (Corylus colurna L.) Wood
}

\author{
Derya Sevim Korkut ${ }^{1}$, Süleyman Korkut ${ }^{1, *}$, Ilter Bekar ${ }^{1}$, Mehmet Budakçı ${ }^{2}$, Tuncer Dilik ${ }^{3}$ \\ and Nevzat Çakıcıer ${ }^{1}$
}

1 Faculty of Forestry, Department of Forest Products Engineering, Duzce University, 81620, Duzce, Turkey. E-Mails: deryasevimkorkut@duzce.edu.tr (D. K.); ilterbekar@duzce.edu.tr (I. B.); nevzatcakicier@duzce.edu.tr (N. C.)

2 Faculty of Technical Education, Department of Furniture and Design, Duzce University, 81620, Duzce, Turkey. E-Mail: mbudakci@gazi.edu.tr

3 Faculty of Forestry, Department of Forest Products Engineering, Istanbul University, 34473, Bahcekoy, Sariyer, Turkey. E-Mail: tuncerd@istanbul.edu.tr

* Author to whom correspondence should be addressed; E-Mails: suleymankorkut@hotmail.com; Tel. +90-380-5421137; Fax: +90-380-5421136

Received: 31 March 2008; in revised form: 11 June 2008 / Accepted: 5 September 2008 / Published: 16 September 2008

\begin{abstract}
Heat treatment is often used to improve the dimensional stability of wood. In this study, the effects of heat treatment on the physical properties and surface roughness of Turkish Hazel (Corylus colurna L.) wood were examined. Samples obtained from Kastamonu Forest Enterprises, Turkey, were subjected to heat treatment at varying temperatures and for different durations. The physical properties of heat-treated and control samples were tested, and oven-dry density, air-dry density, and swelling properties were determined. A stylus method was employed to evaluate the surface characteristics of the samples. Roughness measurements, using the stylus method, were made in the direction perpendicular to the fiber. Four main roughness parameters, mean arithmetic deviation of profile $(\mathrm{Ra})$, mean peak-to-valley height $(\mathrm{Rz})$, root mean square roughness $(\mathrm{Rq})$, and maximum roughness (Ry) obtained from the surface of wood were used to evaluate the effect of heat treatment on the surface characteristics of the specimens. Significant difference was determined $(p=0.05)$ between physical properties and surface roughness parameters ( $\mathrm{Ra}, \mathrm{Rz}, \mathrm{Ry}, \mathrm{Rq})$ for three temperatures and three
\end{abstract}


durations of heat treatment. The results showed that the values of density, swelling and surface roughness decreased with increasing temperature treatment and treatment times. Turkish Hazel wood could be utilized successfully by applying proper heat treatment techniques without any losses in investigated parameters. This is vital in areas, such as window frames, where working stability and surface smoothness are important factors.

Keywords: Turkish Hazel, Corylus colurna L., heat treatment, physical properties, surface roughness.

\section{Introduction}

Hazelnut is a name given to the genus Corylus (Betulaceae) which includes about ten species. The Turkish hazel (Corylus colurna L.) tree is one of the wild species within the genus Corylus. Turkish hazel (Corylus colurna L.) is native to southeast Europe and southwest Asia, from the Balkans through northern Turkey to northern Iran. It is the largest species of hazel, reaching a height of $35 \mathrm{~m}$, with a stout trunk of up to $1.5 \mathrm{~m}$ diameter. It prefers well drained chalky soils. Stems and roots are used by furniture makers for decorative inlays and veneers. The fine lustrous wood is pinkish brown and it polishes beautifully [1].

Heat treatment of wood is an effective method to improve the dimensional stability and durability against biodegradation. Considerable research has focused on the application of heat treatments to improve the dimensional stability, hygroscopic properties and biological resistance of wood. Heat treatments of wood modify chemistry of cell components. These chemical changes can be expressed as increased dimensional stability and decreased hygroscopicity [2-4].

Within the last several years five different types of heat treatments have gained industrial significance in Europe. Some of the products developed by thermal treatment include thermowood in Finland, retification process and bois perdure in France, oil-heat treatment in Germany and plato-wood in The Netherlands [5-7].

The temperature and duration for heat treatment generally vary from 180 to $280^{\circ} \mathrm{C}$ and 15 min to 24 $\mathrm{h}$ depending on the heat treatment process, wood species, sample size, moisture content of the sample, and the desired mechanical properties, resistance to biological attack, and dimensional stability of the final product [8]. Temperature has a greater influence than time on many properties. Treatment at lower temperatures for longer periods, however, does not give similar results compared to treatments at higher temperatures.

Wood treated at high temperature has less hygroscopicity than natural wood. Heating wood permanently changes several of its chemical and physical properties. The change in properties is mainly caused by thermic degradation of hemicelluloses. Theoretically, the available $\mathrm{OH}$ groups in hemicellulose have the most significant effect on the physical properties of wood. Heat treatment lowers water uptake and wood cell wall absorbs less water because of the decrease of the amount of wood's hydroxyl groups. As a consequence of the reduced number of hydroxyl groups the swelling and shrinking are lower. In addition to better durability the advantages of heat treated wood are 
reduced hygroscopicity and improved dimensional stability. It stabilizes around $4-5 \%$ in humidity instead of $10-12 \%$ [9].

Heat-treated wood 'lives' less than untreated wood, meaning that shrinking and swelling is considerably lower. Stamm and Hansen [10] reported that the hygroscopicity of black gum wood decreased to half of its original value when samples were treated at $205^{\circ} \mathrm{C}$ for $6 \mathrm{~h}$. In another study increases in temperature and treatment time, and also the technique used, resulted in changes in dimensional stability from $55 \%$ to $90 \%$ [11]. When young beech, oak, and pine wood was heat treated at 70 to $200{ }^{\circ} \mathrm{C}$ between 6 and $48 \mathrm{~h}$, the effect of heat treatment was obvious after $100^{\circ} \mathrm{C}$, and sorption capacity decreased with increased treatment time and temperature [12].

In addition, heat treatment resulted in varying amounts of weight loss, depending on the treatment temperature and time. In a study on spruce (Picea abies) wood, heat treatment for $24 \mathrm{~h}$ resulted in a weight loss of $0.8 \%$ and $15.5 \%$ at $120^{\circ} \mathrm{C}$ and $200{ }^{\circ} \mathrm{C}$, respectively [13]. Weight loss of beech (Fagus sylvatica) wood, treated at increasing temperatures, was $8.1 \%$ and $9.8 \%$ at $150{ }^{\circ} \mathrm{C}$ and $200{ }^{\circ} \mathrm{C}$, respectively $[14,15]$ reported mass losses of $6.4,7.1$ and $10.2 \%$ for Betula pendula treated at $205{ }^{\circ} \mathrm{C}$ for 4,6 and $8 \mathrm{~h}$.

Heat-treated wood is a new, ecological wood product, which main advantage is the ecological method of manufacture. Heat-treated wood is generally used indoors on parquet and wooden floors, wall and ceiling panels, in saunas and fixed installations for example in the kitchen. It can also be used to make furniture and other utensils, decorations and giftware. Heat-treated wood is rot-resistant enough for many outdoor uses, and this has been achieved without using chemicals that harm the environment or people's health. Heat-treated wood is also an ecological alternative to tropical woods because of the beautiful and pleasant colour it gives [16].

To our knowledge, there is no information about the influence of heat treatment on some physical properties, such as density, swelling, and surface roughness of Turkish hazel wood. This study will hopefully offer the timber products industry many interesting opportunities after demonstrating that heat-treated Turkish hazel woods have improved characteristics.

\section{Experimental Section}

Five trees with a diameter at breast height diameter (DBH. $1.3 \mathrm{~m}$ above ground) of 30-35 cm were obtained from Kastamonu Forest Enterprises [17]. The area from which the trees were taken was at an elevation of 1,290 $\mathrm{m}$ and had a slope of $30 \%$. Lumber from the logs was prepared by Oney Kaplama San. A.Ş. Turkish Hazel lumber was finished by a fixed-knife planer with a feed speed of $1 \mathrm{~m} / \mathrm{s}$. The bias angle of the knife was $45^{\circ}$ for the lumber. If the wood pieces are sawn so that the annual rings are at least in $45^{\circ}$ angle to the surface the deformations will be smaller, the hardness of the surface will be stronger and the "general looks" after heat treatment is better. Sampling and tests were performed according to several Turkish and ISO standards. Small clear samples were obtained for density and swelling $(20 \times 20 \times 30 \mathrm{~mm})$, and surface roughness measurements $(50 \times 50 \times 50 \mathrm{~mm})$.

The samples were subjected to heat treatment at $120^{\circ} \mathrm{C}, 150{ }^{\circ} \mathrm{C}$, or $180{ }^{\circ} \mathrm{C}$ for 2,6 , or $10 \mathrm{~h}$ in a small heating unit controlled to within $\pm 1{ }^{\circ} \mathrm{C}$ under atmospheric pressure. After heat treatment, treated and untreated samples were conditioned at $20 \pm 2{ }^{\circ} \mathrm{C}$ and $65 \%( \pm 5 \%)$ relative humidity (RH) in a conditioning room to reach equilibrium moisture content (EMC) of $12 \%$. The air-dry density of the 
samples was determined. The dimensions and weights of the samples were measured. The oven-dry and air-dry density of the samples was determined at $0.01 \mathrm{~mm}$ and $0.001 \mathrm{~g}$ sensitivity. After the ovendry dimensions were determined, the samples were soaked in water $\left(20 \pm 2{ }^{\circ} \mathrm{C}\right)$. When no changes in sample dimensions were observed, the dimensions were measured. Tests for density (30 samples) and swelling (30 samples) were carried out based on ISO 3131 [18] and TS 4084 [19], respectively.

Surface roughness of the samples was measured using a profilometer (Mitutoyo Surftest SJ-301). Measurements were made with the profile method using a stylus device standard. The measuring speed, pin diameter, and pin top angle of the tool were $10 \mathrm{~mm} / \mathrm{min}, 4 \mu \mathrm{m}$, and $90^{\circ}$, respectively. The points of roughness measurement were randomly marked on the surface of the samples. Measurements were carried out in the direction perpendicular to the fiber of the samples.

Three roughness parameters, mean arithmetic deviation of profile ( $\mathrm{Ra})$, mean peak-to-valley height $(\mathrm{Rz}$ ), and maximum roughness (Ry) were commonly used in previous studies to evaluate surface characteristics of wood and wood composites including veneer [20]. Ra is the average distance from the profile to the mean line over the length of assessment. $\mathrm{Rq}$ is the square root of the arithmetic mean of the squares of profile deviations from the mean line. Rz can be calculated from the peak-to-valley values of five equal lengths within the profile while maximum roughness (Ry) is the distance between peak and valley points of the profile which can be used as an indicator of the maximum defect height within the assessed profile [21]. Therefore, such parameters which are characterized by ISO 4287 [22] and DIN 4768 [23] were recorded.

Figure 1. Schematic description of the Mitutoyo Surftest SJ-301.

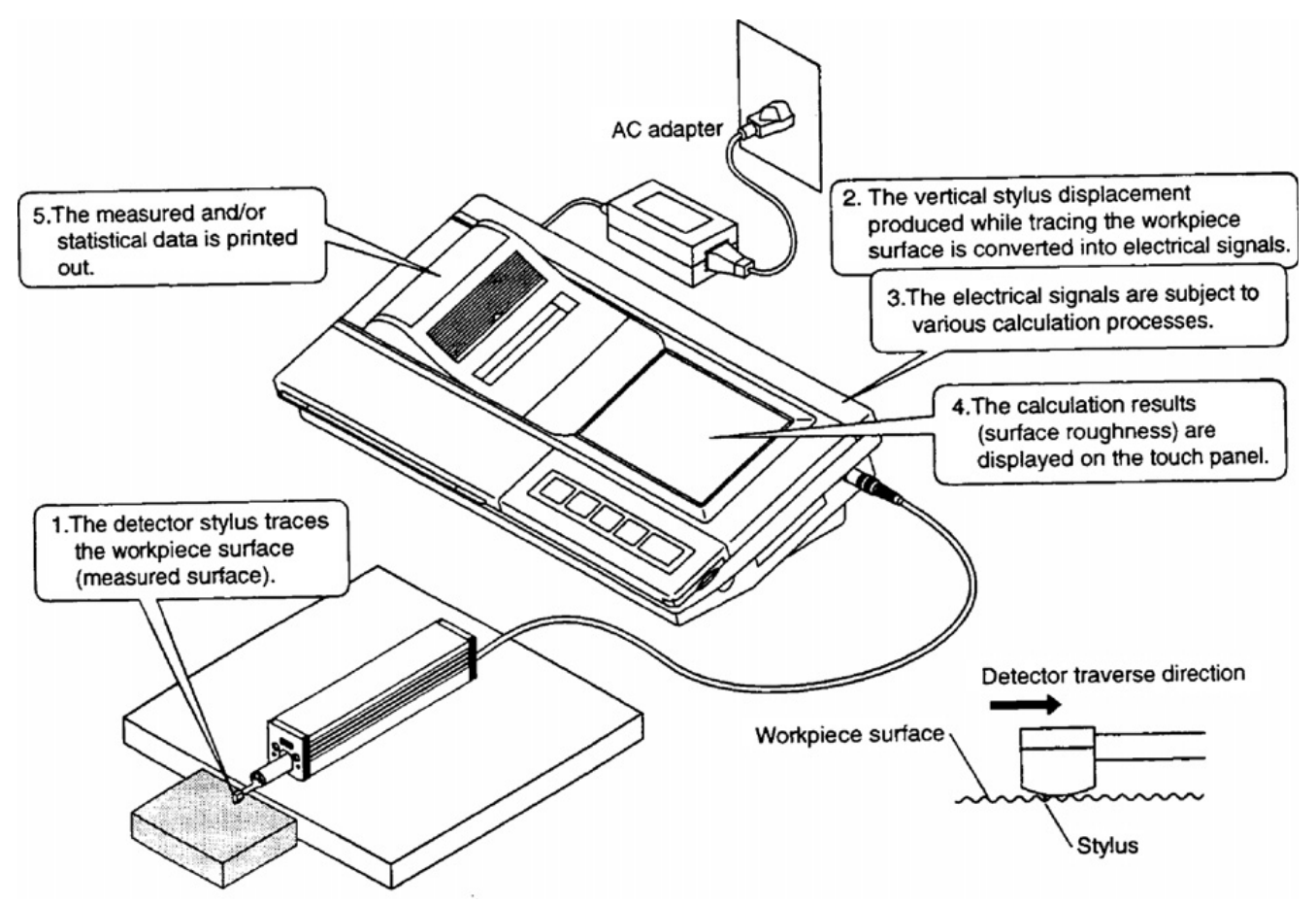

Specification of this parameter is described by Hiziroglu [24], and Hiziroglu and Graham [25]. Roughness values were measured with a sensitivity of $0.5 \mathrm{~lm}$. The length of scanning line (Lt) was 15 $\mathrm{mm}$ and the cut off was $\mathrm{k}=2.5 \mathrm{~mm}$. The measuring force of the scanning arm on the surfaces was 4 
$\mathrm{mN}$ (0.4 g), which did not put any significant damage on the surface according to Mitutoyo Surftest SJ-301 user manual [26]. Measurements were performed at room temperature and the pin was calibrated before the tests. Figure 1 shows the Mitutoyo Surftest SJ-301.

For the oven-dry density, air-dry density, swelling and average roughness, all multiple comparisons were first subjected to an analysis of variance (ANOVA) and significant differences between mean values of control and treated samples were determined using Duncan's multiple range test.

Table 1. The effect of heat treatment for different durations on physical properties and surface roughness in Turkish Hazel (Corylus colurna L.) wood ${ }^{\mathrm{a}}$.

\begin{tabular}{|c|c|c|c|c|c|c|c|c|c|c|c|}
\hline \multirow{2}{*}{$\begin{array}{c}\text { Heat } \\
\text { Treat- } \\
\text { ment }\end{array}$} & \multirow{2}{*}{ Times } & \multirow{2}{*}{ Unit $^{b}$} & $\begin{array}{c}\text { Oven- } \\
\text { dry }\end{array}$ & $\begin{array}{l}\text { Air- } \\
\text { dry }\end{array}$ & \multicolumn{4}{|c|}{ Surface Roughness ${ }^{c}$} & \multicolumn{3}{|c|}{ Swelling } \\
\hline & & & $\begin{array}{c}\text { Do } \\
\left(\mathrm{g} / \mathrm{cm}^{3}\right)\end{array}$ & $\begin{array}{c}D_{12} \\
\left(\mathrm{~g} / \mathrm{cm}^{3}\right)\end{array}$ & $\begin{array}{c}\text { Ra } \\
(\mu \mathrm{m})\end{array}$ & $\begin{array}{c}\text { Ry } \\
(\mu \mathrm{m})\end{array}$ & $\begin{array}{c}\mathrm{Rz} \\
(\mu \mathrm{m})\end{array}$ & $\begin{array}{c}\mathrm{Rq} \\
(\mu \mathrm{m})\end{array}$ & $\begin{array}{c}\text { Radial } \\
(\%)\end{array}$ & $\begin{array}{c}\text { Tange } \\
\text { ntial (\%) }\end{array}$ & $\begin{array}{l}\text { Longitu } \\
\text { dinal(\%) }\end{array}$ \\
\hline \multirow{6}{*}{ Control } & & Avg. & 0.699 & 0.735 & 10.398 & 86.176 & 66.380 & 13.226 & 5.512 & 9.373 & 1.265 \\
\hline & & & A & A & A & A & A & $\mathrm{BA}$ & A & A & A \\
\hline & & $\pm \mathrm{s}$ & 0.062 & 0.063 & 2.613 & 19.275 & 4.909 & 1.213 & 0.266 & 0.494 & 0.237 \\
\hline & & $\mathrm{s}^{2}$ & 0.004 & 0.004 & 6.828 & 371.530 & 24.103 & 1.470 & 0.071 & 0.244 & 0.056 \\
\hline & & V & 8.932 & 8.571 & 25.130 & 22.367 & 7.396 & 9.168 & 4.818 & 5.268 & 18.697 \\
\hline & & $\mathrm{N}$ & 30 & 30 & 30 & 30 & 30 & 30 & 30 & 30 & 30 \\
\hline \multirow{20}{*}{$120^{\circ} \mathrm{C}$} & & Avg. & 0.587 & 0.637 & 10.062 & 83.680 & 65.294 & 12.427 & 5.464 & 9.044 & 1.217 \\
\hline & & & $\mathrm{BCDE}$ & $\mathrm{BFG}$ & $\mathrm{ABCD}$ & $\mathrm{AEF}$ & $\mathrm{ADEF}$ & $\mathrm{AEF}$ & $\mathrm{ABCD}$ & $\mathrm{ACDE}$ & $\mathrm{ACDE}$ \\
\hline & & & FGHIK & HIK & EFGH & $\mathrm{GH}$ & GHI & GH & EFGH & FGHI & FGHI \\
\hline & $2 \mathrm{hr}$. & $\pm \mathrm{s}$ & 0.029 & 0.052 & 0.902 & 12.777 & 15.867 & 0.608 & 0.341 & 1.801 & 0.285 \\
\hline & & $\mathrm{s}^{2}$ & 0.001 & 0.003 & 0.814 & 163.260 & 251.758 & 0.369 & 0.116 & 3.244 & 0.081 \\
\hline & & V & 4.961 & 8.202 & 8.965 & 15.269 & 24.301 & 4.889 & 6.240 & 19.915 & 23.382 \\
\hline & & $\mathrm{N}$ & 30 & 30 & 30 & 30 & 30 & 30 & 30 & 30 & 30 \\
\hline & \multirow{7}{*}{$6 \mathrm{hr}}$. & Avg. & 0.562 & 0.630 & 9.758 & 83.240 & 61.762 & 12.366 & 5.456 & 8.775 & 1.110 \\
\hline & & & $\mathrm{CGH}$ & CFG & $\mathrm{AEF}$ & $\mathrm{AEF}$ & $\mathrm{BFG}$ & $\mathrm{AEF}$ & $\mathrm{ABCD}$ & BHI & BCDE \\
\hline & & & IK & HIK & $\mathrm{GH}$ & GH & HI & GH & EFGH & & FGHI \\
\hline & & $\pm \mathrm{s}$ & 0.059 & 0.076 & 1.962 & 7.073 & 4.602 & 2.390 & 0.156 & 0.740 & 0.256 \\
\hline & & $s^{2}$ & 0.003 & 0.006 & 3.848 & 50.028 & 21.177 & 5.712 & 0.024 & 0.547 & 0.066 \\
\hline & & V & 10.482 & 12.006 & 20.104 & 8.497 & 7.451 & 19.326 & 2.855 & 8.430 & 23.104 \\
\hline & & $\mathrm{N}$ & 30 & 30 & 30 & 30 & 30 & 30 & 30 & 30 & 30 \\
\hline & \multirow{6}{*}{$10 \mathrm{hr}$} & Avg. & 0.559 & 0.624 & 9.140 & 79.500 & 60.982 & 11.830 & 5.122 & 8.481 & 0.902 \\
\hline & & & DHIK & DGHIK & BGH & BEFGH & CFGHI & $\mathrm{BFGH}$ & BEFGH & CHI & CGHI \\
\hline & & $\pm \mathrm{s}$ & 0.024 & 0.048 & 0.889 & 18.919 & 10.582 & 1.139 & 0.595 & 0.967 & 0.146 \\
\hline & & $\mathrm{s}^{2}$ & 0.001 & 0.002 & 0.790 & 357.928 & 111.978 & 1.298 & 0.354 & 0.935 & 0.021 \\
\hline & & V & 4.288 & 7.673 & 9.723 & 23.797 & 17.353 & 9.632 & 11.622 & 11.398 & 16.173 \\
\hline & & $\mathrm{N}$ & 30 & 30 & 30 & 30 & 30 & 30 & 30 & 30 & 30 \\
\hline
\end{tabular}


Table 1. Cont.

\begin{tabular}{|c|c|c|c|c|c|c|c|c|c|c|c|}
\hline \multirow{18}{*}{$150^{\circ} \mathrm{C}$} & \multirow{6}{*}{$2 \mathrm{hr}$} & \multirow[t]{2}{*}{ Avg. } & 0.555 & 0.612 & 9.026 & 79.288 & 60.496 & 11.782 & 5.046 & 8.308 & 0.897 \\
\hline & & & EIK & EGHIK & $\mathrm{CGH}$ & CEFGH & DFGHI & $\mathrm{CFGH}$ & CEFGH & DHI & DGHI \\
\hline & & $\pm \mathrm{s}$ & 0.031 & 0.014 & 1.689 & 10.358 & 9.119 & 1.088 & 0.173 & 0.744 & 0.179 \\
\hline & & $\mathrm{s}^{2}$ & 0.001 & 0.0002 & 2.853 & 107.294 & 83.149 & 1.183 & 0.030 & 0.554 & 0.032 \\
\hline & & V & 5.666 & 2.296 & 18.713 & 13.064 & 15.073 & 9.232 & 3.422 & 8.958 & 19.907 \\
\hline & & $\mathrm{N}$ & 30 & 30 & 30 & 30 & 30 & 30 & 30 & 30 & 30 \\
\hline & & Avg. & 0.552 & 0.603 & 8.946 & 79.136 & 60.252 & 11.658 & 4.988 & 8.282 & 0.884 \\
\hline & & & FIK & FHIK & DGH & DEFGH & EFGHI & DFGH & DFGH & EHI & EHI \\
\hline & $6 \mathrm{hr}$ & $\pm \mathrm{s}$ & 0.042 & 0.057 & 0.794 & 10.910 & 6.771 & 2.020 & 0.435 & 1.044 & 0.258 \\
\hline & o nा. & $s^{2}$ & 0.002 & 0.003 & 0.630 & 119.034 & 45.843 & 4.079 & 0.189 & 1.091 & 0.066 \\
\hline & & V & 7.543 & 9.438 & 8.870 & 13.787 & 11.237 & 17.324 & 8.722 & 12.611 & 29.153 \\
\hline & & $\mathrm{N}$ & 30 & 30 & 30 & 30 & 30 & 30 & 30 & 30 & 30 \\
\hline & & Avg. & 0.538 & 0.581 & 8.786 & 70.820 & 54.694 & 11.094 & 4.813 & 8.233 & 0.832 \\
\hline & & & GIK & GIK & EGH & EFGH & FHI & EGH & $\mathrm{EH}$ & FHI & FHI \\
\hline & $10 \mathrm{hr}$ & $\pm \mathrm{s}$ & 0.025 & 0.042 & 1.798 & 9.447 & 8.197 & 1.800 & 0.217 & 1.666 & 0.321 \\
\hline & $10 \mathrm{ill}$. & $s^{2}$ & 0.001 & 0.002 & 3.234 & 89.242 & 67.186 & 3.239 & 0.047 & 2.776 & 0.177 \\
\hline & & $\mathrm{V}$ & 4.629 & 7.199 & 20.470 & 13.339 & 14.986 & 16.223 & 4.512 & 20.239 & 38.581 \\
\hline & & $\mathrm{N}$ & 30 & 30 & 30 & 30 & 30 & 30 & 30 & 30 & 30 \\
\hline & & Avg. & 0.534 & 0.558 & 8.468 & 63.938 & 54.234 & 10.714 & 4.703 & 8.195 & 0.749 \\
\hline & & & HIK & $\mathrm{H}$ & FGH & $\mathrm{FH}$ & GHI & FGH & FH & GHI & GI \\
\hline & $2 \mathrm{hr}$ & $\pm \mathrm{s}$ & 0.037 & 0.027 & 2.405 & 8.365 & 3.999 & 2.743 & 0.462 & 0.820 & 0.227 \\
\hline & $2 \mathrm{hr}$. & $\mathrm{s}^{2}$ & 0.001 & 0.001 & 5.785 & 69.967 & 15.993 & 7.525 & 0.213 & 0.672 & 0.107 \\
\hline & & V & 6.994 & 4.765 & 28.403 & 13.082 & 7.374 & 25.603 & 9.822 & 10.004 & 30.307 \\
\hline & & $\mathrm{N}$ & 30 & 30 & 30 & 30 & 30 & 30 & 30 & 30 & 30 \\
\hline & & Avg. & 0.514 & 0.551 & 7.216 & 59.146 & 48.235 & 9.168 & 4.650 & 7.582 & 0.662 \\
\hline & & & I & I & G & G & $\mathrm{H}$ & G & $\mathrm{GH}$ & $\mathrm{H}$ & $\mathrm{H}$ \\
\hline $180^{\circ} \mathrm{C}$ & $6 \mathrm{hr}$ & $\pm \mathrm{s}$ & 0.036 & 0.039 & 0.787 & 6.567 & 6.616 & 0.902 & 0.625 & 0.581 & 0.250 \\
\hline $180{ }^{\circ}$ & o nr. & $s^{2}$ & 0.001 & 0.001 & 0.619 & 43.128 & 43.765 & 0.813 & 0.390 & 0.338 & 0.062 \\
\hline & & V & 6.964 & 7.008 & 10.902 & 11.103 & 13.715 & 9.837 & 13.436 & 7.666 & 37.718 \\
\hline & & $\mathrm{N}$ & 30 & 30 & 30 & 30 & 30 & 30 & 30 & 30 & 30 \\
\hline & & Avg. & 0.511 & 0.534 & 6.615 & 56.846 & 47.106 & 8.724 & 4.393 & 7.168 & 0.568 \\
\hline & & & K & $\mathrm{K}$ & $\mathrm{H}$ & $\mathrm{H}$ & I & $\mathrm{H}$ & $\mathrm{H}$ & I & I \\
\hline & $10 \mathrm{hr}$ & $\pm \mathrm{s}$ & 0.019 & 0.010 & 0.900 & 7.848 & 3.111 & 1.240 & 0.138 & 0.510 & 0.147 \\
\hline & $10 \mathrm{nr}$. & $\mathrm{s}^{2}$ & 0.0004 & 0.0001 & 0.810 & 61.595 & 9.678 & 1.537 & 0.019 & 0.260 & 0.021 \\
\hline & & V & 3.789 & 1.905 & 13.605 & 13.806 & 6.604 & 14.211 & 3.146 & 7.116 & 25.809 \\
\hline & & $\mathrm{N}$ & 30 & 30 & 30 & 30 & 30 & 30 & 30 & 30 & 30 \\
\hline
\end{tabular}

${ }^{\mathrm{a}}$ Number of samples used in each test is $20 .{ }^{\mathrm{b}}$ Avg. $=$ average; $\pm \mathrm{s}=$ standard deviation; $\mathrm{s}^{2}=$ variance. $\mathrm{V}=$ coefficient of variation. $\mathrm{N}=$ number of samples used in each test. ${ }^{\mathrm{c}}$ Homogenous groups: letters in each column indicate groups that are statistically different according to Duncan's multiple range test at $\mathrm{P}<0.05$. Comparisons were between each control and its test. 


\section{Results and Discussion}

Table 1 shows the oven-dry and air-dry densities and swelling ratios under the different heat treatment and time combinations. According to the averages, all the parameters decreased with increasing temperature and time. It is evident from the results that these values were all lower in heattreated samples than in control samples. The effect of the heat treatments was significant for all the variables analyzed. It is clear from this study that the value of all measured physical properties and surface roughness decreased with increasing temperature and duration.

Heating wood permanently changes several of its chemical and physical properties. The change in properties is mainly caused by thermic degrading of hemicelluloses. Theoretically, the available $\mathrm{OH}$ groups in hemicellulose have the most significant effect on the physical properties of wood. Heat treatment slows water uptake and wood cell wall absorbs less water because of the decrease of the amount of wood's hydroxyl groups. As a consequence of the reduced number of hydroxyl groups the swelling and shrinking are lower. In addition to better durability the advantages of heat-treated wood are reduced hygroscopicity and improved dimensional stability. Heat treatment significantly reduces the tangential and radial swelling. The wood's swelling and shrinkage is very low. Desired changes start to appear already at about $150{ }^{\circ} \mathrm{C}$, and the changes continue as the temperature is increased in stages [27].

Table 2 shows the percentage decrease of values in relation to the control for each treatment and each measured parameter.

Table 2. Percentage decrease of physical properties and surface roughness in Turkish Hazel (Corylus colurna L.) wood following heat treatment for different durations.

\begin{tabular}{|c|c|c|c|c|c|c|c|c|c|c|}
\hline \multirow{3}{*}{$\begin{array}{c}\text { Heat } \\
\text { Treat- } \\
\text { ment }\end{array}$} & \multirow{3}{*}{$\begin{array}{c}\text { Time } \\
\text { (h) }\end{array}$} & \multirow{2}{*}{$\begin{array}{c}\text { Oven- } \\
\text { dry } \\
\text { density }\end{array}$} & \multirow{2}{*}{$\begin{array}{l}\text { Air-dry } \\
\text { density }\end{array}$} & \multicolumn{3}{|c|}{ Swelling } & \multicolumn{4}{|c|}{ Surface Roughness } \\
\hline & & & & Radial & $\begin{array}{r}\text { Tang } \\
\text { ential }\end{array}$ & $\begin{array}{c}\text { Longi } \\
\text { tudinal }\end{array}$ & Ra & Ry & $\mathbf{R z}$ & Rq \\
\hline & & $\%$ & $\%$ & $\%$ & $\%$ & $\%$ & $\%$ & $\%$ & $\%$ & $\%$ \\
\hline \multirow{3}{*}{$120{ }^{\circ} \mathrm{C}$} & 2 & 15.95 & 13.33 & 0.87 & 3.51 & 3.80 & 3.23 & 2.90 & 1.64 & 6.04 \\
\hline & 6 & 19.57 & 14.28 & 1.02 & 6.38 & 12.30 & 6.16 & 3.41 & 6.96 & 6.50 \\
\hline & 10 & 20.04 & 15.04 & 7.08 & 9.51 & 28.68 & 12.10 & 7.75 & 8.13 & 10.55 \\
\hline \multirow{3}{*}{$150{ }^{\circ} \mathrm{C}$} & 2 & 20.54 & 16.72 & 8.44 & 11.36 & 29.12 & 13.19 & 7.99 & 8.86 & 10.92 \\
\hline & 6 & 20.99 & 17.86 & 9.49 & 11.64 & 30.16 & 13.96 & 8.17 & 9.23 & 11.86 \\
\hline & 10 & 23.02 & 20.94 & 12.67 & 12.17 & 34.26 & 15.50 & 17.82 & 17.60 & 16.12 \\
\hline \multirow{3}{*}{$180{ }^{\circ} \mathrm{C}$} & 2 & 23.51 & 24.09 & 14.67 & 12.56 & 40.82 & 18.56 & 25.81 & 18.30 & 18.99 \\
\hline & 6 & 26.41 & 25.06 & 15.63 & 19.11 & 47.71 & 30.60 & 31.37 & 27.34 & 30.68 \\
\hline & 10 & 26.90 & 27.36 & 20.29 & 23.53 & 55.13 & 36.38 & 34.03 & 29.04 & 34.04 \\
\hline
\end{tabular}

It is evident from Table 1 that the oven-dry density and air-dry density values decrease with increasing temperature and heat treatment time under the conditions used. Heat treated wood samples at a temperature of $180{ }^{\circ} \mathrm{C}$ for $10 \mathrm{~h}$ gave the lowest air-dry and oven-dry density values when compared with other conditions studied. 
It is known that the weight of wood material decreases when heat treatment is applied. These changes resulting from heat treatment could be explained by losses in the cell wall, extractive substances and hemicellulose degradation due to the high temperature applied.

Decreases in swelling to radial, tangential and longitudinal directions were found to be $20.29 \%$, $23.53 \%$, and $55.13 \%$, respectively, when treated at $180{ }^{\circ} \mathrm{C}$ for $10 \mathrm{~h}$. A decrease in swelling results in an increase in dimensional stability, which is required for several uses of wood.

Surface roughness can be affected by various factors such as annual ring width, differences between juvenile and mature wood, density, differences between early and late wood and specific cell structures [28].

Surface roughness decreased by nearly $37 \%$ in the sample heat-treated at $180{ }^{\circ} \mathrm{C}$ for $10 \mathrm{~h}$ when compared with the control samples. This increase in smoothness or decrease in roughness is very important for many applications of solid wood. In addition, losses occurring in the planning machine are reduced and high quality surfaces are attained.

It may be concluded that the heat treatment resulted a plastification on the solid wood surfaces. High temperatures above $160{ }^{\circ} \mathrm{C}$ cause lignin to a thermoplastic condition and thus to densify and compact solid wood surface [29, 30].

Also, the wooden materials with rough surface requires much more sanding process compared to one with smooth surface, which leads to decrease in thickness of material and, therefore, increase the losses due to the sanding process [28, 31].

The maximum decreases for all parameters were recorded at the treatment of $180{ }^{\circ} \mathrm{C}$ for $10 \mathrm{~h}$. The lowest oven-dry density values obtained was $0.511 \mathrm{gr} / \mathrm{cm}^{3}$, total loss compared to the control was calculated to be $26.90 \%$. Similarly, the lowest air-dry density was also obtained for samples treated at $180{ }^{\circ} \mathrm{C}$ for $10 \mathrm{~h}\left(0.534 \mathrm{gr} / \mathrm{cm}^{3}\right)$. The air-dry density loss was $27.36 \%$ when compared to the control.

The parameters measured varied in their rates of decrease with some experiencing a gradual loss and others exhibiting more dramatic changes (Figure 2). Heat treatment resulted in varying amounts of weight loss, depending on the treatment temperature and time.

In general the results of this study on the effect of heat treatment on Turkish Hazel are compatible with the findings in literature on the effect of heat treatment on different tree species. Yildiz [31] reported that the density observed for beech $(2.25 \%)$ and spruce $(1.73 \%)$ woods treated at $130{ }^{\circ} \mathrm{C}$ for 2 $\mathrm{h}$ was higher than that of control samples. On the other hand, at longer treatment times and higher temperatures, the density decreased. The highest decrease in density was observed in samples treated at $200^{\circ}$ for $10 \mathrm{~h}$ (beech, $18.37 \%$ decrease; beech spruce, $10.53 \%$ decrease). The increase in dimensional stability was calculated to be $50 \%$ for beech and $40 \%$ for spruce wood. Similar results were also observed when samples were treated in an inert gas atmosphere at $180-200{ }^{\circ} \mathrm{C}$ and $8-10$ bar of atmospheric pressure (beech, 10-15\% density decrease; spruce, 5-10\% decrease) [32]. In another study, the dimensional stability was $60 \%$ higher for oak heartwood, $55 \%$ higher for pine heart- and sapwood, and 52\% higher for spruce heart- and sapwood after heat treatment [33].

Unsal and Ayrilmis [34] also found that the maximum surface roughness decrease in Turkish river red gum (Eucalyptus camaldulensis Dehn.) wood samples was $27.9 \%$ at $180{ }^{\circ} \mathrm{C}$ for $10 \mathrm{~h}$. Korkut [35] obtained similar oven-dry and air-dry density, swelling and surface roughness values for Uludag fir (Abies bornmuellerinana Mattf.) wood for the same treatment time and temperature. 
Figure 2. Percentage decrease of physical properties in Turkish Hazel (Corylus colurna L.) wood following heat treatment for different durations. $(\diamond)$ oven-dry density; $(\square)$ air-dry density; $(\Delta)$ radial swelling; $(\mathrm{x})$ tangential swelling; (*) longitudinal swelling; (o) surface roughness $(\mathrm{Ra})$

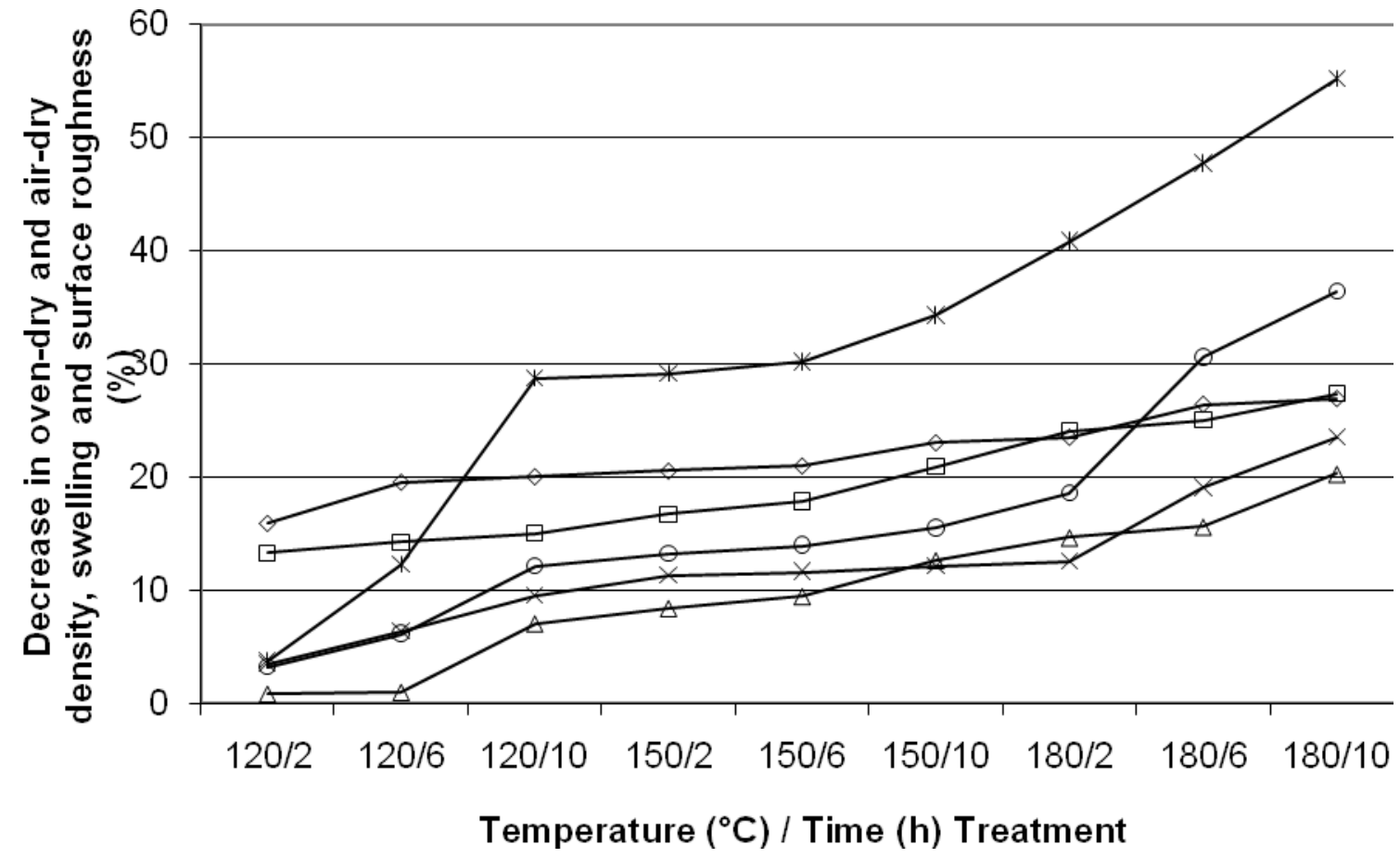

Unsal et al. [36] reported that in Turkish river red gum (Eucalyptus camaldulensis Dehn.) wood samples the largest swelling loss was at $180{ }^{\circ} \mathrm{C}$ after $10 \mathrm{~h}$ treatment. The loss was $14.11 \%$ radially, and $21.51 \%$ tangentially. Oven-dry density decreased by up to $11.76 \%$ in the sample heat-treated at $180{ }^{\circ} \mathrm{C}$ for $10 \mathrm{~h}$ when compared with the control samples.

Esteves et al. [37] reported that in Pinus pinaster and Eucalyptus globulus wood samples in the absence of air by steaming, treatment inside an autoclave heated at $190-210{ }^{\circ} \mathrm{C}$ for $2-12 \mathrm{~h}$ resulted in an equilibrium moisture content decrease by $46 \%$ for pine and $61 \%$ for eucalyptus, while the dimensional stability increased (maximum anti-shrinking efficiency in the radial direction of 57 and $90 \%$ for pine and eucalyptus, respectively) and the surface wettability was lowered. Mass losses increased with treatment time and temperature, reaching $7.3 \%$ for pine and $14.5 \%$ for eucalyptus wood. The wood behaviour towards moisture was improved.

These results can be explained by material losses in the cell lumen and hemicellulose degradation due to the high applied temperature. It is known that the weight of wood material and its swelling decreases when heat treatment is applied. Heat treatment lowers water uptake and wood cell wall absorbs less water because of the decrease of the amount of hydroxyl groups in the wood. As a consequence of the reduced number of hydroxyl groups, the swelling and shrinking were lower [11].

\section{Conclusions}

In conclusion, it was found that the density, swelling and surface roughness of the Turkish Hazel decreased for all treatment conditions (temperatures and times). The smallest decrease was observed in 
the treatment at $120^{\circ} \mathrm{C}$ for $2 \mathrm{~h}$. The largest decrease found was for swelling, followed by $\mathrm{Ra}$ and the air-dry density, when samples were heat-treated under the specific conditions of this research.

The improved characteristics in swelling and surface roughness of heat treated timber have to be balanced against the decrease in strength values when evaluating the effectiveness of using this treatment. This wood species can be utilized by applying adequate heat-treatment techniques that result in negligible losses in density values in areas where working, stability, and surface smoothness are important factors. Due to its good weather resistance, thermowood is suited for outdoor applications such as external cladding, paneling, parquets, sauna, window frames and garden furniture.

The improved characteristics of heat treated timber offer the timber product industry many potential and attractive new opportunities. The most important property, when compared to untreated wood, is that the equilibrium moisture content of the heat-treated wood is reduced and as a consequence of this shrinkage and swelling of the wood is also reduced. The best way of utilizing heat-treated timber is to make use of these improved properties.

\section{References and Notes}

1. Yaltirik, F.; Efe, A. Dendrology Handbook, Gymnospermae-Angiospermea; Faculty of Forestry Publication, University of Istanbul Publication: Istanbul, Turkey, 2000.

2. Ifju, G. Tensile strength behavior as a function of cellulose in wood. Forest Prod. J. 1964, 14, 366-372.

3. Yilgor, N.; Unsal, O.; Kartal, S.N. Physical, mechanical, and chemical properties of steamed beech wood. Forest Prod. J. 2001, 51, 89-93.

4. Kartal, S.N.; Hwang, W.J.; Imamura, Y. Combined effect of boron compounds and heat treatments on wood properties: Chemical and strength properties of wood. J. Mater. Process. Tech. 2008, 198, 234-240.

5. Viitaniemi, P.; Jämsä, S. Modification of wood with heat treatment (in Finnish); VTT julkaisuja publicationer Espoo, Technical Research Center of Finland 1996; volume 57.

6. Militz, H. Thermal treatment of wood: European processes and their background. In $33^{\text {rd }}$ Annual Meeting, IRG/WP 02-40241, Cardiff, Wales, May 2002; volume 4, pp. 1-17.

7. Jǒšćak, T.; Mamoňová, M.; Babiak, M.; Teischinger, A.; Müller, U. Effects of high temperature drying in nitrogen atmosphere on mechanical and colour properties of Norway spruce. Holz RohWerkst. 2007, 65, 285-291.

8. Kamdem, D.P.; Pizzi, A.; Jermannaud, A. Durability of heattreated wood. Holz Roh-Werkst. 2002, 60, 1-6.

9. Inoue, M.; Norimoto, M.; Tanahashi, M.; Rowell, R.M. Steam or heat fixation of compressed wood. Wood Fiber Sci. 1993, 25, 224-235.

10. Stamm, A.J.; Hansen, L.A. Minimizing wood shrinkage and swelling: Effect of heating in various gases. Ind. Eng. Chem. 1937, 29, 831-833.

11. Yildiz, S.; Gezer, E.D.; Yıldı, U.C. Mechanical and chemicalbehavior of spruce wood modified by heat. Build. Environ. 2006, 41, 1762-1766.

12. Kollmann, F.; Schneider, A. The sorption behavior of heat-treated wood. Holz Roh-Werkst. 1963, 21, 77-85. 
13. Fengel, D. On the changes of the wood and its components within the temperature range up to $200{ }^{\circ} \mathrm{C}-$ Part III: Thermally and Mechanically Caused Structural Changes in Sprucewood. Holz Roh-Werkst. 1966, 24, 529-536.

14. Fengel, D.; Wegener, G. Wood: Chemistry, Ultrastructure, Reactions; Walter de Gruyter: Berlin, Germany, 1984.

15. Zaman, A.; Alen, R.; Kotilainen, R. Thermal behavior of Pinus sylvestris and Betula pendula at 200-230 ${ }^{\circ}$ C. Wood Fiber Sci. 2000, 32, 138-143.

16. Rapp, A.O. Review on heat treatments of wood. In Proceedings of Special Seminar, Antibes, France, February 2001.

17. TS 4176. Wood-sampling sample trees and logs for determination of physical and mechanical properties of wood in homogeneous stands. TSE: Ankara, Turkey, 1984.

18. ISO 3131. Wood-determination of density for physical and mechanical tests. International Organization for Standardization: Geneva, Switzerland, 1975.

19. TS 4084. Wood-Determination of Radial and Tangential Swelling. TSE: Ankara, Turkey, 1983.

20. Stombo, D.A. Surface texture measurement. Forest Prod. J. 1963, 13, 299-304.

21. Mummery, L. Surface Texture Analysis. The Handbook. Muhlhausen: Hommelwerke, Germany, 1993; p. 106.

22. ISO 4287. Geometrical product specifications (GPS) surface texture: profile method-terms, definitions, and surface texture parameters. International Organization for Standardization: Geneva, Switzerland, 1997.

23. DIN 4768. Determination of roughness parameters $R a, R z$, Rmax by means of stylus instruments. terms, measuring conditions. Deutsches Institut für Normung: Berlin, Germany, 1990.

24. Hiziroglu, S.S. Surface roughness analysis of wood composites: a stylus method. Forest Prod. J. 1963, 46, 67-72.

25. Hiziroglu, S.S.; Graham, S. Effect of press closing time and target thickness on surface roughness of particleboard. Forest Prod. J. 1998, 48, 50-54.

26. Anonymous. Mitutoyo Surface Roughness Tester - Mitutoyo Surftest SJ-301; Mitutoyo Corporation: Kanagawa, Japan, 2002.

27. Anonymous. ThermoWood Handbook. Finnish Thermowood Association: Helsinki, Finland, 2003.

28. Dündar, T; As, N.; Korkut, S.; Unsal, Ö. The effect of boiling time on the surface roughness of rotary-cut veneers from oriental beech (Fagus orientalis L.). J. Mater. Process. Tech. 2008, 199, 119-123.

29. Follrich, J.; Muller, U.; Gindl, W. Effects of thermal modification on the adhesion between spruce wood (Picea abies Karst.) and a thermoplastic polymer. Holz Roh-Werkst 2006, 64, 373-376.

30. Ayrilmis, N.; Winandy, J.E.; Laufenberg, T.L. Effects of post thermal-treatment on wettability, surface roughness, and adhesive bonding performance of exterior medium density fiberboard. Polym. Degrad. Stabil. 2008, submitted.

31. Yildiz, S. Physical, mechanical, technological and chemical properties of beech and spruce wood treated by heating. Ph.D. Thesis; Black Sea Technical University: Trabzon, Turkey, 2002.

32. Feist, W.C.; Sell, J. Weathering behaviour of dimensionally stabilized wood treated by heating under pressure of nitrogen gas. Wood Fiber Sci. 1987, 19, 183-195. 
33. Burmester, A. Effect of heat-pressure treatments of semi-dry wood on its dimensional stability. Holz Roh- Werkst. 1973, 31, 237-243.

34. Unsal, O.; Ayrilmis, N. Variations in compression strength and surface roughness of heat-treated Turkish river red gum (Eucalyptus camaldulensis Dehn.) wood. J. Wood Sci. 2005, 51, 405-409.

35. Korkut, S. The effects of heat treatment on some technological properties in Uludag fir (Abies bornmuellerinana Mattf.) wood. Build. Environ. 2008, 43, 422-428.

36. Unsal, O.; Korkut, S.; Atik, C. The effect of heat treatment on some properties and colour in eucalyptus (Eucalyptus camaldulensis Dehn.) wood. MADERAS: Cienc. Tecnol. 2003, 2, $145-152$.

37. Esteves, B.; Marques, A.V.; Domingos, I.; Pereira, H. Influence of steam heating on the properties of pine (Pinus pinaster) and eucalypt (Eucalyptus globulus) wood. Wood Sci. Technol. 2007, 41, 193-207.

(C) 2008 by the authors; licensee Molecular Diversity Preservation International, Basel, Switzerland. This article is an open-access article distributed under the terms and conditions of the Creative Commons Attribution license (http://creativecommons.org/licenses/by/3.0/). 